\title{
REGIONAL BLOOD FLOW IN THE EPIDIDYMIS OF THE RAT AND RABBIT: EFFECT OF EFFERENT DUCT LIGATION AND ORCHIDECTOMY
}

\author{
PATRICIA D. G. BROWN* AND G. M. H. WAITES $\dagger$ \\ Department of Physiology, University of Sydney, \\ Sydney, N.S.W., Australia
}

(Received 3rd February 1971, accepted 26th March 1971)

\begin{abstract}
Summary. Relative blood flow along the epididymis of the rat and rabbit has been measured using the isotope fractionation technique of Sapirstein (1958). In the rabbit, by simultaneously measuring cardiac output by the thermodilution technique, blood flow was expressed in absolute units.

In both species, portions of the caput and corpus regions were nourished by capillaries with high blood flow whereas the cauda had the lowest blood flow in the epididymis.

Blood flow values \pm S.E.M. recorded in fourteen rabbit epididymides were: mean blood flow $23.8 \pm 1.9 \mathrm{ml} / 100 \mathrm{~g} / \mathrm{min}$; high blood flow regions were: segments 2 and 3 , caput epididymidis (34.8 $\pm 2 \cdot 3$ and $34 \cdot 3 \pm 2 \cdot 2$ $\mathrm{ml} / 100 \mathrm{~g} / \mathrm{min}$ ), and the corpus epididymidis (36.0 $\pm 0.9 \mathrm{ml} / 100 \mathrm{~g} / \mathrm{min})$. Cauda epididymidis blood flow was $19.7 \pm 1.8 \mathrm{ml} / 100 \mathrm{~g} / \mathrm{min}$.

There was no bilateral variation in blood flow in the testis or epididymis of rat or rabbit.

Removal of one testis or unilateral ligation of the efferent ducts caused a marked reduction of capillary blood flow in the caput region of both rat and rabbit epididymides after 7 days compared with the control epididymis. The effect was less striking elsewhere in the epididymis.

The region of rich capillary blood flow in the corpus epididymidis in the rabbit coincides with the portion of the duct in which spermatozoa acquire the ability to fertilize.
\end{abstract}

\section{INTRODUCTION}

In recent years, interest has been focused on regional differences in the function of the epididymis. The cells lining the duct differ in size, structure and cytochemistry (rat: Reid \& Cleland, 1957; Reid, 1958; Martan \& Risley, 1963; rabbit: Nicander, 1957, see Discussion). The caput epididymidis is believed to have a reabsorptive function (see Discussion). Glycerylphosphorylcholine is synthesized in the caput and cauda regions of the epididymis (Dawson, Mann

* Present address: Department of Veterinary Physiology, University of Sydney, Australia.

$\dagger$ Present address: Department of Physiology and Biochemistry, University of Reading, England. 
\& White, 1957; Dawson \& Rowlands, 1959; Scott, Wales, Wallace \& White, 1963) and, if other substances arise in this way by local secretion, the composition of the fluid in the lumen at any point will be governed by the balance between secretion and absorption across the wall of the duct and the requirements of the spermatozoa.

The most striking specialization, however, is that of the spermatozoa themselves. From being infertile and relatively immotile on entry into the epididymis, they become able to fertilize and capable of motility in the rabbit as they pass through the duct of the corpus epididymidis (for review, see OrgebinCrist, 1969). This fact is arresting and poses again (Young, 1931) the question of whether the capacity to fertilize is inherent within the spermatozoa or is derived from the secretions of the epididymis.

Cells with widely differing metabolic rates have widely differing capillary blood flow; for example, the kidney cortex, medulla and hilum (Thorburn, Kopald, Herd, Hollenberg, O'Morchoe \& Barger, 1963) and different regions of the brain (Kety, 1960). Indeed, Haddy \& Scott (1968) concluded that capillary blood flow and cellular metabolic rate are closely linked. For this reason, studies of regional blood flow in the epididymis not only have direct interest, but may also indicate which portions of the duct have particular functional significance.

The epididymides of the rat and ram have been shown to have a similar pattern of regional blood flow (Setchell, Waites \& Till, 1964). The present experiments were planned:

(1) to re-examine the pattern of epididymal blood flow in the rat, and to look for any bilateral discrepancy as found in the mouse (Bindon \& Waites, 1968);

(2) to examine this pattern in the rabbit, the species concerned in most of the studies on the fertilizing ability of epididymal spermatozoa;

(3) to examine if the pattern of epididymal blood flow was altered by preventing the entry of testicular spermatozoa and fluid into the epididymis.

\section{METHODS}

\section{Relative blood flow}

Rats. The isotope fractionation technique (Sapirstein, 1958, 1962, 1967) was used to obtain relative blood flow (RBF) estimates (Waites \& Setchell, 1966). SpragueDawley and Wistar rats (weight 150 to $450 \mathrm{~g}$ ) were anaesthetized with an intraperitoneal injection of pentobarbitone sodium (approximately $5 \mathrm{mg} / 100 \mathrm{~g} \mathrm{~b} . \mathrm{wt}$ ). About $25 \mu \mathrm{Ci}\left[{ }^{131} \mathrm{I}\right], 4$-iodoantipyrine (Radiochemical Centre, Amersham, England) in $0.5 \mathrm{ml} 0.9 \%$ saline was rapidly injected into a jugular vein and the rats were killed $40 \mathrm{sec}$ later by isolating the heart with a double-bladed guillotine. The following tissues were removed: brain, testes and epididymides, the latter were cut up as shown (Text-fig. 1). The radioactive content of these tissues was determined in a sodium iodide well-counter and scaler (Ecko Electronics, Type N530g).

Rabbits. In the isotope fractionation technique, the indicator must have attained 'plateau' concentrations in the organ when the circulation is arrested. To determine this 'plateau', rabbits were anaesthetized with pentobarbitone 
sodium (Sagatal, May \& Baker Ltd, $30 \mathrm{mg} / \mathrm{kg}$ ), and the collimated 5-mm endwindow of a Geiger-Müller tube placed over the testis and the caput and cauda epididymidis. In separate tests, the level of radioactivity in these organs was recorded on a rate meter and potentiometric pen recorder (Rikadenki Koygo Co. Ltd) during $5 \mathrm{~min}$ after the injection of approximately $10 \mu \mathrm{Ci}\left[{ }^{131} \mathrm{I}\right], 4$-iodoantipyrine. A plateau level of isotope was attained by $30 \mathrm{sec}$ and remained until 70 to $100 \mathrm{sec}$ after the injection.

In experiments designed to measure blood flow in the testis and epididymis, rabbits were, therefore, killed $60 \mathrm{sec}$ after the injection of isotope. For these experiments, a PVG catheter $(0.58 \mathrm{~mm}$ i.d.: $0.96 \mathrm{~mm}$ o.d., Dural Plastics, N.S.W., Australia) filled with heparin-saline was inserted through the marginal ear vein under local anaesthesia so that the tip lay near the junction of the jugular vein and superior vena cava. Forty-eight hours later, about $50 \mu \mathrm{Ci}$ [ ${ }^{131} \mathrm{I}$ ],4-iodoantipyrine in $1 \mathrm{ml} 0.9 \%$ saline were rapidly injected through this catheter as the rabbit sat quietly in a box. After $50 \mathrm{sec}$, an overdose of a saturated solution of pentobarbitone sodium (May \& Baker Ltd, Dagenham, England) was injected down the catheter and the rabbit was decapitated when anaesthetized, at $60 \mathrm{sec}$. The following tissues were removed: brain (eleven rabbits), seminal vesicles (thirteen), testes (ten control and fourteen treated rabbits) and epididymides (ten control and fourteen treated rabbits).

The epididymides were dissected into ten pieces in the control rabbits (Text-fig. 1), and twelve pieces in the treated rabbits (as in Text-fig. 3 ).

\section{Cardiac output}

Cardiac output was measured by the thermodilution technique (Fegler, 1954, 1957) in seven control and twelve treated rabbits in which relative blood flow was also determined. The two values when multiplied together yield absolute blood flow (see Sapirstein, 1956; Waites \& Setchell, 1966). The technique followed was that described by Korner (1965).

Thermistors (Stantel U23 UD, Standard Telephone and Cables Pty Ltd) were mounted in the tip of a PVC catheter $(0.58 \mathrm{~mm}$ i.d.:0.96 mm o.d. or $0.5 \mathrm{~mm}$ i.d.: $0.8 \mathrm{~mm}$ o.d.). Only the thermistors with a $90 \%$ response time of $<1 \mathrm{sec}$ for a temperature change of 39 to $20^{\circ} \mathrm{C}$ and a linear calibration of resistance change versus temperature were accepted.

The indicator used was $0.5 \mathrm{ml} 0.9 \%$ saline at room temperature; the temperature was measured before each injection with a mercury-in-glass thermometer calibrated to $0.05^{\circ} \mathrm{C}$. The heat gained by the indicator as it passed down an equivalent length of catheter at $39^{\circ} \mathrm{C}$ (rabbit body temperature) was calculated by calorimetry.

Flow in the range 0 to $500 \mathrm{ml} / \mathrm{min}$ in a model circulation was measured directly and by thermodilution. Close agreement was obtained $(r=0.97$, $1.05 \mathrm{ml}$ indicator volume; $\mathrm{r}=0.95,0.5 \mathrm{ml}$ ).

Rabbits were anaesthetized $48 \mathrm{hr}$ before the experiments with either pentobarbitone sodium or halothane (Fluothane, I.C.I.) and the thermistors were inserted either through an iliolumbar artery (Korner, 1965), or through a femoral artery, to lie in the aorta at the level of the renal arteries. Usually, test thermodilution curves were recorded before the rabbit recovered. The ther- 
mistor wires were brought out of the abdomen through a stab incision and were protected by a leather jacket.

Five thermodilution curves were recorded at 5-min intervals 24 and $48 \mathrm{hr}$ after inserting the thermistor and with the rabbit sitting quietly in a box. Blood flow by the isotope fractionation technique was then estimated, as described, within $5 \mathrm{~min}$ of recording the last thermodilution curve.

Cardiac output was measured on each of 6 successive days in one rabbit, and for $\mathbf{8}$ days in another, to determine if the cardiac output measured on the second day after the operation was a representative value.

Recirculation of the indicator was excluded from the thermodilution curves by extrapolation; the area obtained was determined by computer and from this, the cardiac output was calculated (see Hosie, 1962).

\section{Operations}

Rats. Under barbiturate anaesthesia, thirty-four rats were unilaterally castrated and, in another forty-three, the efferent ducts of one testis were ligated. In all rats, the testes were delivered through a short incision in the scrotum. The testicular artery was tied (4/0 silk, Johnson \& Johnson) and cut between ligatures placed below the origin of the epididymal arteries. The testis was removed and the epididymis returned inside the tunica vaginalis being careful not to create torsion. In the other experiments, the efferent ducts were tied (4/0 silk) as close to the testis as possible, and the testis and epididymis replaced inside the tunica vaginalis. In all operations, the control testis and epididymis were taken out and then put back into the scrotum through a similar incision.

Rabbits. Fourteen animals were anaesthetized with pentothal (Thiopentone sodium, Abbott Laboratories Pty Ltd, $25 \mathrm{mg} / \mathrm{kg}$ body weight) for unilateral castration under sterile conditions. The testis and epididymis of one side were exposed through a midline incision in the scrotum. The epididymis was dissected off the testis which was then removed after ligating the testicular vessels distal to the origin of the epididymal vessels. The epididymis was replaced in the scrotum, the tunica vaginalis closed with medium chromic catgut (Ethnor Pty Ltd, Sydney, 4/0) and the scrotal skin sutured (Mersilene, Braided Polyester suture, Ethicon, 4/0).

\section{Experimental procedure in animals subjected to operation}

Rats. Relative blood flow was determined (a) 1, 2, 3 and 4 weeks after unilateral castration, and (b) 1 day, and 1, 2, 3 and 4 weeks after efferent duct ligation.

Rabbits. Blood flow measurements were made 7 days (in five), 14 days (four) and 21 days (five) after unilateral castration. Two days before the measurements, a catheter was inserted into a marginal ear vein and a thermistor was inserted into the aorta, as for the control rabbits. Five thermodilution curves for the calculation of cardiac output were recorded 24 and $48 \mathrm{hr}$ later when relative blood flow was measured, as described, within $5 \mathrm{~min}$ of recording the last thermodilution curve. 


\section{Histology}

The structure of the epididymis of rats and rabbits after unilateral castration was examined using the Feulgen reaction after fixation in Stieve's fixative.

\section{RESULTS}

Relative blood flow in the rat epididymis

Control. The pattern of relative blood flow observed in the epididymides of twelve control rats (Text-fig. 1), agreed with that obtained earlier (Setchell $e t$ $a l .$, 1964). Capillary blood flow was high in the portion of the epididymal duct nearest to the testis (caput, Segment 1) and in the corpus epididymidis. There was no bilateral variation in the blood flow of either the testis (relative blood flow: left, $1 \cdot 59 \pm 0.057$; right, $1 \cdot 70 \pm 0.060$ ) or epididymis (Text-fig. 1).

After operation. Blood flow in the epididymis was unchanged 1 day after efferent duct ligation.

The pattern of relative blood flow became more uniform along the length of the epididymis 1 week after both operations to prevent entry of testicular fluid and spermatozoa (Text-fig. 2). The major effect was in the part nearest to the testis (caput, Segment 1) in which relative blood flow was reduced on the side of the operation compared with the control. This occurred after both efferent duct ligation (EDL) and unilateral castration (UC) and appeared 1 week after the operation (mean change, control blood flow $=100 \%$ : EDL $-11 \%$ : UC $-7 \%$ ) and reached a maximum at 2 weeks $(-18 \% ;-35 \%)$ and 3 weeks $(-21 \%, P<0.05 ;-34 \%, P<0.001$, Text-fig. 2), being less at 4 weeks $(-7 \% ;-22 \%)$. A similar but less marked effect was observed in the caput, Segment 2 (Text-fig. 2).

Blood flow in the corpus and cauda regions of the epididymis was relatively unaffected by the operations (Text-fig. 2). However, 3 weeks after unilateral castration, relative blood flow in the contralateral corpus epididymidis was lower $(0.83 \pm 0.075)$ than in either the experimental epididymis of the same rats $(1 \cdot 16 \pm 0 \cdot 040 ; P<0.001)$ or the corpus region in control rats (Text-fig. 1$)$.

\section{Cardiac output and blood flow in the rabbit epididymis}

Cardiac output. The cardiac output of seven conscious male rabbits (body weight $2.86 \mathrm{~kg} \pm 0 \cdot 13$ ) recorded $48 \mathrm{hr}$ after the operation to insert the aortic thermistor was $24 \cdot 3 \mathrm{ml} \pm 2 \cdot 3 \mathrm{ml} / 100 \mathrm{~g}$ body weight $/ \mathrm{min}$ (Table 1).

In two rabbits, cardiac output on Day 2 after operation when rabbits were killed to measure absolute blood flow in the epididymis was $92 \%$ of the mean of daily values measured during Days 3 to 6 and 3 to 8, respectively.

Blood flow in the rabbit epididymis. In the control, the pattern of capillary blood flow along the epididymal duct was constant whether expressed as relative blood flow (ten rabbits; Text-fig. 1), or absolute blood flow (seven rabbits; Text-fig. 3). Mean blood flow \pm S.E.M. in the rabbit epididymis was $23 \cdot 8 \pm 1 \cdot 9$ $\mathrm{ml} / 100 \mathrm{~g} / \mathrm{min}$ (fourteen epididymides), but two regions received above average blood flow. These were the caput epididymidis, Segments 2 and $3(34 \cdot 8 \pm 2 \cdot 3$ and $34 \cdot 3 \pm 2 \cdot 2 \mathrm{ml} / 100 \mathrm{~g} / \mathrm{min}$, respectively), and the corpus epididymidis $(36 \cdot 0 \pm$ 
$0.9 \mathrm{ml} / 100 \mathrm{~g} / \mathrm{min})$. Blood flow to the cauda epididymidis was consistently lower than to any other part $(19.7 \pm 1.8 \mathrm{ml} / 100 \mathrm{~g} / \mathrm{min})$.

There was no bilateral variation in blood flow in the testis or epididymis (Table 2).

Following unilateral orchidectomy, cardiac output was reduced by approximately $25 \%$ after 14 to 21 days (Table 1 ). Although blood flow to the control

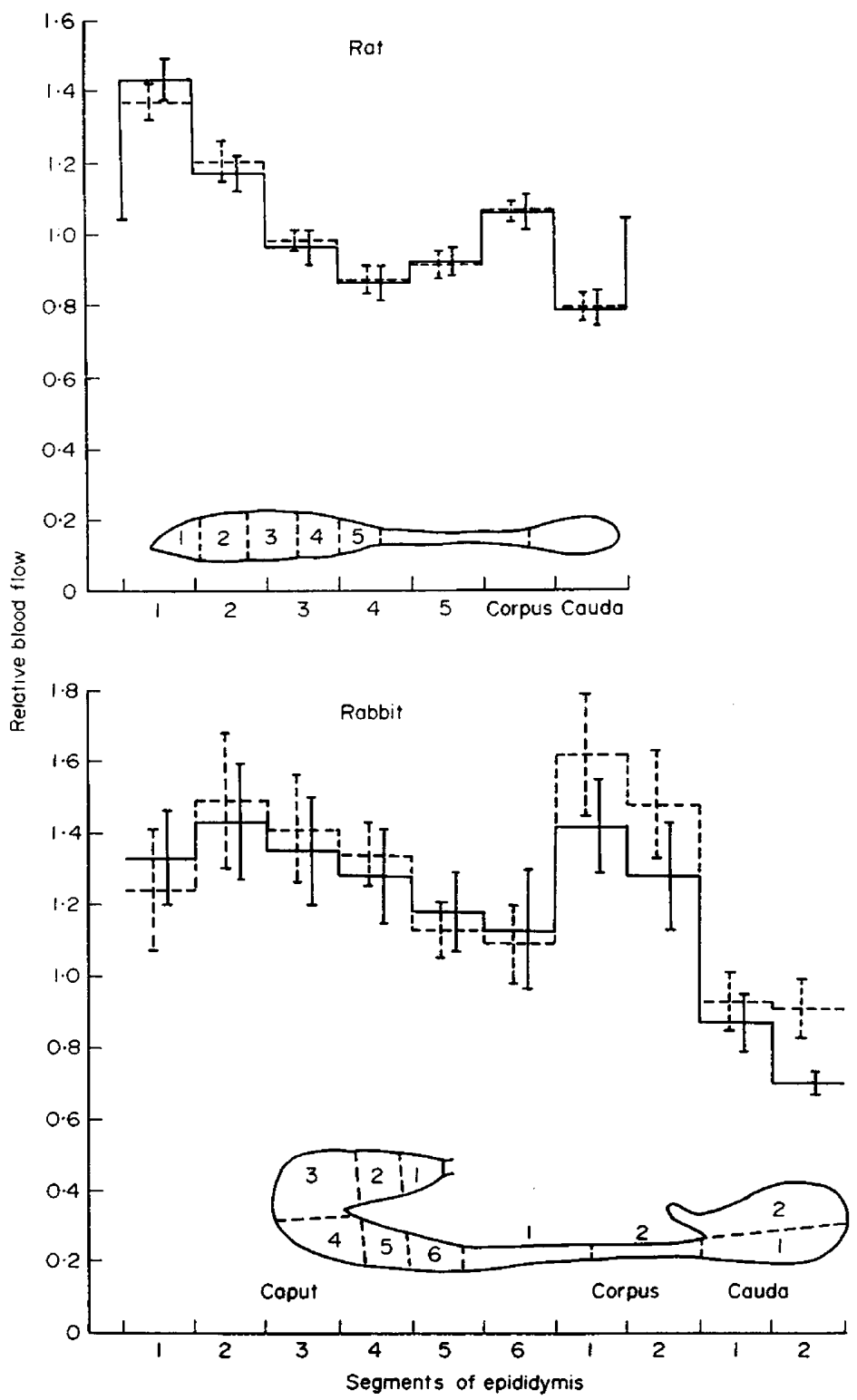

TExT-FIG. 1. Relative blood flow (mean \pm S.E.M.) in the epididymis of the rat $(\mathbf{n}=12$ ) and rabbit $(n=10)$. Comparison between each segment of left $(---)$ and right $(-)$ epididymides by paired $t$ test revealed non-significant differences except for cauda, Segment 2 in the rabbit $(P<0.05)$. 
epididymides was reduced by a similar amount (Text-fig. 3), their pattern of blood flow was unaltered. In the testis-deprived epididymides of the same rabbits, the trend was for absolute blood flow to be less in all regions except the cauda. The overall effect was to make epididymal blood flow uniform, with statistically significant reductions in the proximal segments of the caput after 14 and 21 days (Text-fig. 4).

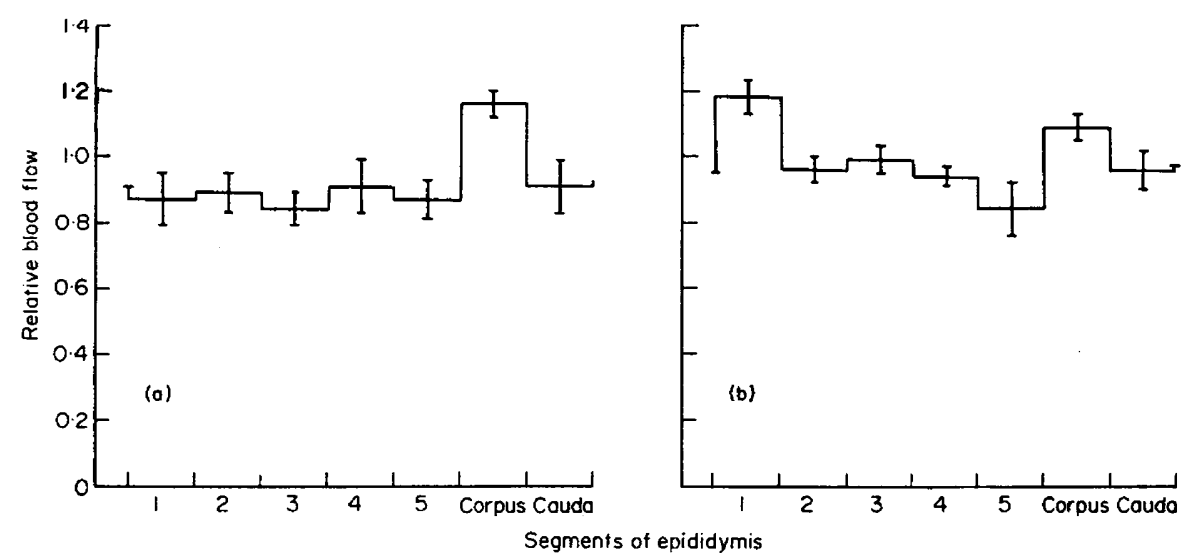

TEXT-Fig. 2. Relative blood flow (mean \pm S.E.M.) on the side of the operation in the epididymides of rats 3 weeks after (a) removal of one testis (ten rats); (b) unilateral ligation of the efferent ducts (eight rats). Compare with pattern of control rats in Textfig. 1.

TABLE 1

CARDIAC OUTPUT OF CONTROL AND UNILATERALLY CASTRATED MALE RABBITS

\begin{tabular}{c|c|c|c}
\hline \multirow{2}{*}{ Control } & \multicolumn{3}{|c}{ Days after unilateral castration } \\
\cline { 2 - 4 } & 7 & 14 & 21 \\
\hline $24 \cdot 3 \pm 2 \cdot 3$ & $\begin{array}{c}19 \cdot 6 \pm 5 \cdot 4 \\
(2)\end{array}$ & $\begin{array}{c}17 \cdot 7 \pm 1 \cdot 5 \\
(5)\end{array}$ & $\begin{array}{c}18 \cdot 4 \pm 3 \cdot 7 \\
(5) \\
\text { N.S. }\end{array}$ \\
& N.S. & N.S. & N.S. \\
\hline
\end{tabular}

Values expressed in $\mathrm{ml} / 100 \mathrm{~g} / \mathrm{min} \pm$ S.E.M.

Number of rabbits shown in parentheses.

N.S. $=$ not significant.

Blood flow in other tissues after unilateral castration

Testis. Blood flow in the remaining testis was reduced 14 and 21 days after removal of one testis, compared with control values, by an amount proportional to the reduction of cardiac output (compare Tables 2 and 3 ).

Despite this, there was evidence of a compensatory weight increase by 21 days. The bilateral difference of testis weight of ten control rabbits was $0.064 \mathrm{~g}$ (average testis weight $1.76 \mathrm{~g}$ ), whereas 21 days after removing one testis 
(average weight: $2.09 \mathrm{~g}$ ) from five rabbits, the remaining testes were on average $0.32 \mathrm{~g}$ heavier.

Seminal vesicles. Although the weight of the seminal vesicles was unchanged by unilateral castration, their blood flow was reduced to less than half that of control values, a greater fall than could be attributed to the change of cardiac output (Table 3 ).

Brain. Blood flow through the brain was also lower per unit weight after unilateral castration, again by an amount that could be accounted for by a reduction in perfusion due to cardiac output changes (Table 3 ).

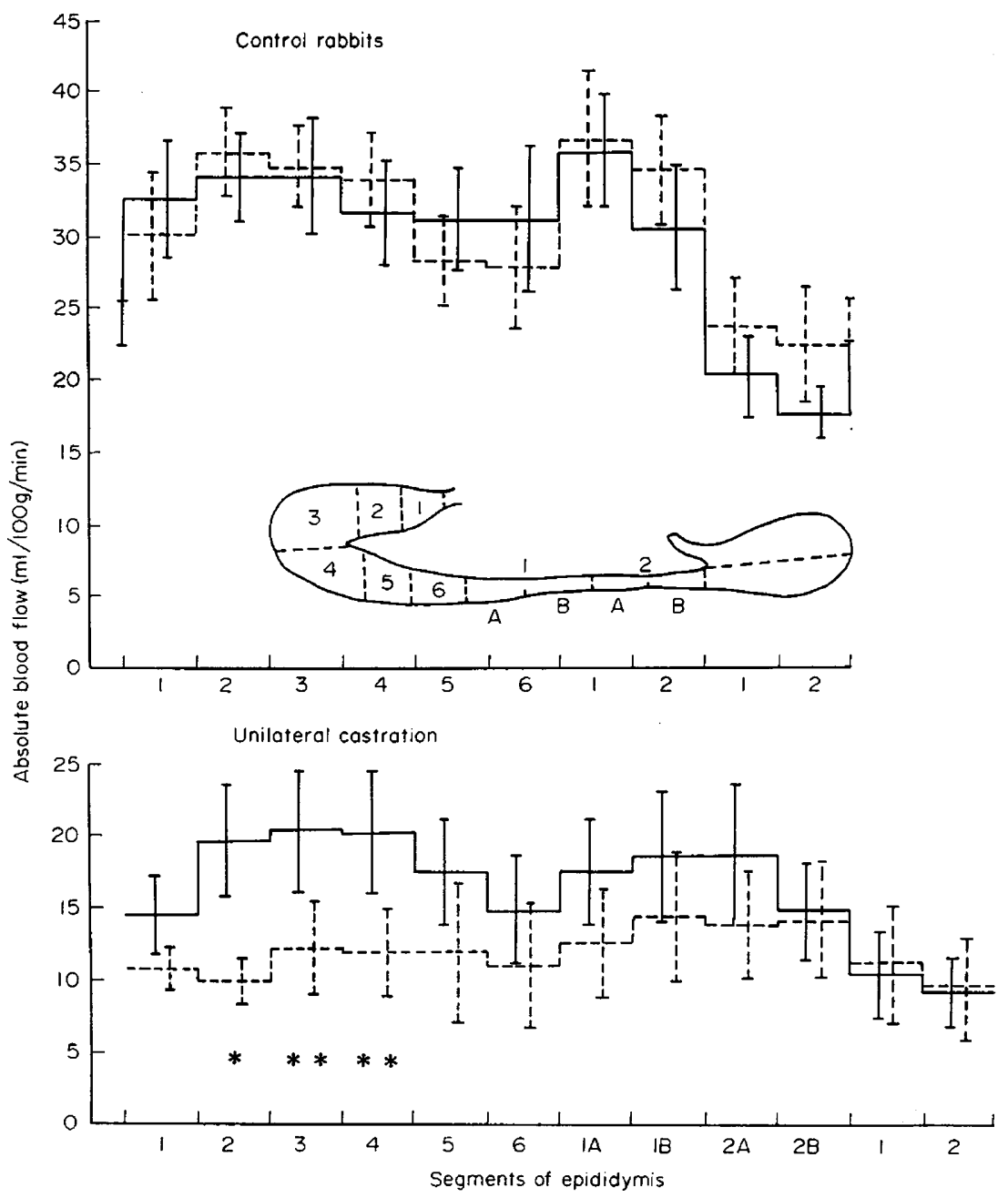

Text-Fig. 3. Absolute blood flow $(\mathrm{ml} / 100 \mathrm{~g} / \mathrm{min}$; mean \pm S.E.M.) in the left $(---)$ and right $(-$ ) epididymides of control rabbits (above; $n=7$ ) and rabbits unilaterally castrated 21 days before (control epididymis -; $n=5$ ). Comparison between each segment of left versus right (control rabbits) and side of control versus side of operation (unilaterally castrated rabbits) revealed non-significant differences except where indicated: * $P<0.05 ;{ }^{* *} P<0.02$. 


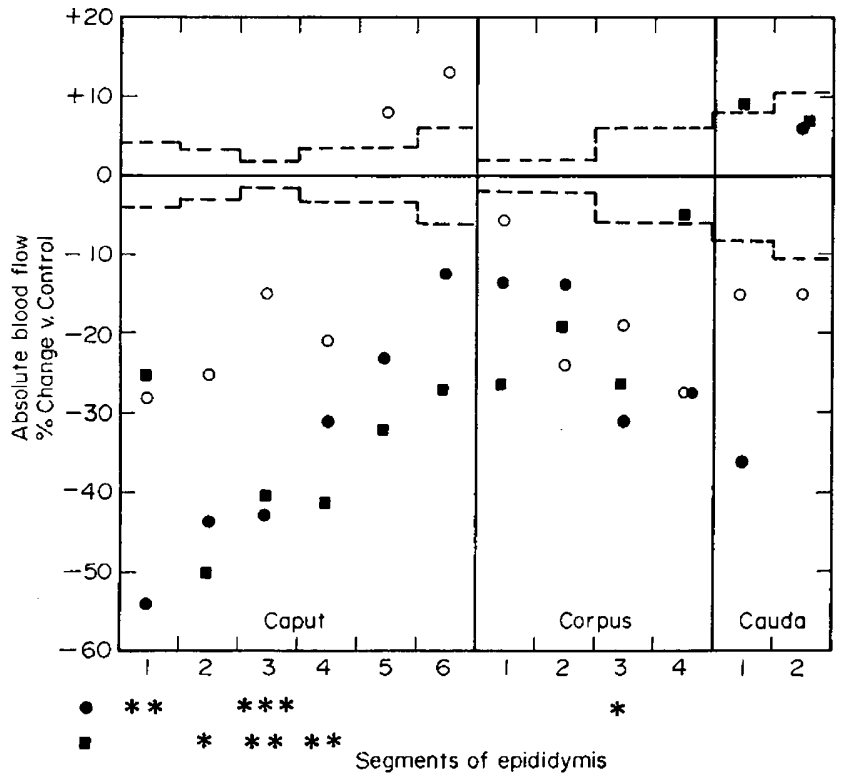

TEXT-FIG. 4. Change of absolute blood flow in the epididymis of the rabbit after unilateral castration. Blood flow in the epididymis on the side of the operation plotted as $\%$ of the control epididymis: 0,7 days (mean of two rabbits); 0,14 days $(n=4) ; \boldsymbol{d}, 21$ days $(n=5)$ after operation; $=- \pm=$ bilateral variation in epididymal blood flow of seven control rabbits (see Text-fig. $\overline{3}$ ). Comparison of blood flow between each segment of the epididymis on the control side versus the side of the operation revealed non-significant differences at 7 days, but significant differences where shown at $14(\bullet)$ and 21 ( days: $* P<0.05 ; * * P<0.02 ;{ }^{* * *} P<0.001$.

TABLE 2

TISSUE BLOOD FLOW IN MALE RABBITS

\begin{tabular}{|c|c|c|c|c|c|c|}
\hline \multicolumn{2}{|c|}{ Testis } & \multicolumn{2}{|c|}{ Epididymis } & \multirow{2}{*}{$\begin{array}{c}\begin{array}{c}\text { Seminal } \\
\text { vesicles }\end{array} \\
\begin{array}{c}31 \cdot 2 \pm 1 \cdot 5 \\
(2)\end{array}\end{array}$} & \multirow{2}{*}{$\frac{\begin{array}{c}\text { Hind leg } \\
\text { muscle }\end{array}}{13 \cdot 4 \pm 3 \cdot 1}$} & \multirow{2}{*}{$\begin{array}{c}\text { Brain } \\
\begin{array}{c}57 \cdot 9 \\
(1)\end{array}\end{array}$} \\
\hline $\begin{array}{c}23 \cdot 6 \pm 2 \cdot 2 \\
(7)\end{array}$ & $\underset{(7)}{23 \cdot 9 \pm 2 \cdot 9}$ & $\begin{array}{c}22 \cdot 3 \pm 2 \cdot 3 \\
(7)\end{array}$ & $\frac{25 \cdot 4 \pm}{(7)} 3 \cdot 0$ & & & \\
\hline \multicolumn{2}{|c|}{ N.S. } & \multicolumn{2}{|c|}{ N.S } & & & \\
\hline
\end{tabular}

Values expressed in $\mathrm{ml} / 100 \mathrm{~g} / \mathrm{min} \pm \mathrm{S} . \mathrm{E} . \mathrm{M}$.

Number of rabbits shown in parentheses.

N.S. = not significant.

TABLE 3

EFFECT OF UNILATERAL GASTRATION FOR 14 AND 21 DAYS ON TISSUE BLOOD FLOW IN RABBITS

\begin{tabular}{|c|c|c|c|c|c|c|}
\hline \multirow{2}{*}{$\begin{array}{c}\text { Tissue blood } \\
\text { flow }\end{array}$} & \multicolumn{2}{|c|}{ Remaining testis } & \multicolumn{2}{|c|}{ Seminal vesicles } & \multicolumn{2}{|c|}{ Brain } \\
\hline & 14 days & 21 days & 14 days & 21 days & 14 days & 21 days \\
\hline $\begin{array}{l}\mathrm{ml} / 100 \mathrm{~g} / \mathrm{min} \pm \\
\text { S.E.M. } \\
\text { (no. of rabbits) }\end{array}$ & $\underset{(4)}{19 \cdot 7 \pm 2 \cdot 9}$ & $\underset{(5)}{16 \cdot 8 \pm 2 \cdot 9}$ & $\frac{12 \cdot 6 \pm}{(4)} 1 \cdot 4$ & $\underset{(5)}{10 \cdot 1 \pm 1 \cdot 9}$ & $\underset{(4)}{33 \cdot 8 \pm 1 \cdot 9}$ & $\frac{36 \cdot 9 \pm 4 \cdot 5}{(5)}$ \\
\hline $\begin{array}{l}\% \text { Change versus } \\
\text { control (Table } 2 \text { ) }\end{array}$ & -17 & -29 & -56 & -68 & $-28 \dagger$ & $-22 \dagger$ \\
\hline
\end{tabular}

† Compared with $47 \cdot 1 \mathrm{ml} / 100 \mathrm{~g} / \mathrm{min}$ (Smith \& Waites, 1969). 


\section{DISCUSSION}

The isotope fractionation technique (Sapirstein, 1958) gives a measure of the volume of blood flow in capillaries, called 'relative blood flow' by Waites \& Setchell (1966). The technique permits an instantaneous comparison of blood flow in neighbouring capillary networks in the same animal. It is particularly useful when comparing bilateral differences within the one animal, as in the present experiments when the effect of surgical intervention on one side was compared with the control contralateral side. However, as Sapirstein (1958) pointed out, there must be care in the choice of indicator and in the period allowed for it to circulate. Tissue blood flow can only be expressed in absolute units if cardiac output is measured at the same time. This has been achieved in conscious rabbits in the present study.

Cardiac output and tissue blood flow; effect of unilateral orchidectomy

The cardiac output of conscious male rabbits reported in this study $(24 \cdot 3 \pm$ $2.3 \mathrm{ml} / 100 \mathrm{~g}$ body weight/min) agrees with that reported by Korner (1965) for conscious male rabbits $(21.4 \mathrm{ml} / 100 \mathrm{~g}$ body weight $/ \mathrm{min})$ and Smith \& Waites (1969) for conscious female rabbits $(22.5 \mathrm{ml} / 100 \mathrm{~g}$ body weight $/ \mathrm{min}$ ) using the same technique. Neutze, Wyler \& Rudolph (1968), using dye dilution, recorded a value of $21.5 \mathrm{ml} / 100 \mathrm{~g} / \mathrm{min}$ in conscious male rabbits.

The reduction of cardiac output 2 and 3 weeks after unilateral orchidectomy is worthy of comment although it is as yet without explanation. The reduced cardiac output coincided with a corresponding reduction of blood flow in the remaining testis (Table 3). Blood flow in the brain was also reduced by an amount corresponding to cardiac output when values for cerebral blood flow measured in the same conditions in the same laboratory are used as controls (Smith \& Waites, 1969). The exception is that blood flow through the seminal vesicles fell to approximately one third control values after unilateral castration, although tissue weight remained unchanged.

\section{Blood flow in the epididymis}

The patterns of blood flow in the epididymis of the rat and rabbit are remarkably characteristic and confirm in the rat the pattern previously reported (Setchell et al., 1964). The constant feature is that portions of the caput and corpus epididymidis were nourished by capillaries with a high blood flow whereas the terminal portions of the epididymis always received the lowest blood flow (Text-figs. 1 and 3). There were no bilateral differences in epididymal or testicular blood flow in the rat or rabbit, in contrast to the mouse in which the right testis and epididymis received a higher blood flow than the left (Bindon \& Waites, 1968).

The fluid secreted by the testis is thought to be reabsorbed in the caput epididymidis, from experiments involving serial ligations of the proximal part of the epididymis (van Wagenen, 1924, 1925; Toothill \& Young, 1931; Macmillan, 1954; Baillie, 1962), observations on the uptake of dyes injected into the testis (Gunn, 1936; Mason \& Shaver, 1952; Shaver, 1954; Grant, 1958; Nicander, 1965) and serial measurements of sperm and electrolyte 
concentrations along the epididymal duct (Crabo \& Gustafsson, 1964; Crabo, 1965). As the volumes of fluid produced in the rat and ram testis are large (rat: Tuck, Setchell, Waites \& Young, 1970; ram: Voglmayr, Waites \& Setchell, 1966), the high capillary blood flow in the caput region may be associated with differential fluid reabsorption.

Unilateral castration and unilateral ligation of the efferent ducts were followed by reductions of capillary blood flow in the caput epididymidis (Textfigs. 2 to 4 ). This might be further evidence of a relationship between fluid reabsorption and high blood flow. The fluid entering the epididymis of the ram contains testosterone (Voglmayr et al., 1966; see Setchell, 1970), which may be supporting the cells lining the duct, although recent evidence suggests that epididymal cells themselves may be able to synthesize testosterone (Hamilton, Jones \& Fawcett, 1969; Hamilton \& Fawcett, 1970). Both operations would presumably change the hormonal environment of the duct whereas overall steroid levels would be less affected as one or both testes remain. It might be expected that the effect should appear along the epididymis at a rate proportional to fluid and sperm transport. The vascular effect was not immediate. Although the caput epididymidis was empty of spermatozoa 3 days after removing the testis in both the rat and rabbit, blood flow in this region exhibited a non-significant fall by 7 days, which became statistically significant by 14 and 21 days.

The second region of high capillary blood flow is in the corpus epididymidis. In the rabbit, absolute blood flow is higher here than in any other region and, as in the cauda region also, was less susceptible to change after operation than blood flow in the caput. This region of rich capillary blood flow coincides with that portion of the epididymis in the rabbit in which spermatozoa acquire the ability to fertilize (Bedford, 1966; Orgebin-Crist, 1968, 1969) and where the epithelial cells are most active in converting acetate to dehydroepiandrosterone and testosterone (Hamilton, 197l). As the spermatozoa take only $6 \mathrm{hr}$ to pass through this part of the duct, the nature of the relationship between the microcirculation and the epididymal cells here would seem to warrant further investigation.

\section{ACKNOWLEDGMENTS}

We wish to thank Professor P. I. Korner and Dr B. P. Setchell for helpful discussions, and $\mathrm{Mr} \mathrm{H}$. G. Smith and Mr D. Quinlan for assistance during the experiments. The work was supported by grants to G.M.H.W. from the Australian Research Grants Committee and the Population Council Inc., New York.

\section{REFERENCES}

BAILliE, A. H. (1962) Observations comparing the effects of epididymal obstruction at various levels on the mouse testis with those of ischaemia. 7. Anat. 96, 335.

BEDFord, J. M. (1966) Development of the fertilising ability of spermatozoa in the epididymis of the rabbit. F. exp. Zool. 163, 319.

Bindon, B. M. \& WaItes, G. M. H. (1968) Discrepancy in weight and blood flow of the left and right testis and epididymis of the mouse before and after hypophysectomy. F. Endocr. 40, 385.

Crabo, B. (1965) Studies on the composition of epididymal content in bulls and boars. Acta vet. scand. 6, Suppl. 5. 
Grabo, B. \& Gustafsson, B. (1964) Distribution of sodium and potassium and its relation to sperm concentration in the epididymal plasma of the bull. 7. Reprod. Fert. 7, 337.

Dawson, R. M. G., ManN, T. \& White, I. G. (1957) Glycerylphosphorylcholine and phosphorylcholine in semen and their relation to choline. Biochem. $7.65,627$.

Dawson, R. M. C. \& Rowlands, I. W. (1959) Glycerylphosphorylcholine in the male reproductive organs of rats and guinea-pigs. Q. Fl exp. Physiol. 44, 26.

FegleR, G. (1954) Measurement of cardiac output in anaesthetized animals by a thermodilution method. Q. Fl exp. Physiol. 39, 153.

Fegler, G. (1957) The reliability of the thermodilution method for determination of the cardiac output and the blood flow in central veins. Q. Fl exp. Physiol. 42, 254.

Grant, J. H. (1958) The passage of trypan blue through the epididymis and its uptake by this organ. Proc. Soc. Study Fert. 10, 95.

Gunn, R. M. C. (1936) Fertility in sheep. Aust. Coun. scient. ind. Res. Bull. No. 94, 1.

HADDY, F. J. \& ScOTt, J. B. (1968) Metabolically linked vasoactive chemicals in local regulation of blood flow. Physiol. Rev. 48, 688.

Hamilton, D. W. (1971) Steroid function in the mammalian epididymis. F. Reprod. Fert. Suppl. 13, 89.

Hamilton, D. W. \& Fawcett, D. W. (1970) In vitro synthesis of cholesterol and testosterone from acetate by rat epididymis and vas deferens. Proc. Soc. exp. Biol. Med. 133, 693.

Hamilton, D. W., Jones, A. L. \& Fawcett, D. W. (1969) Cholesterol biosynthesis in the mouse epididymis and ductus deferens: a biochemical and morphological study. Biol. Reprod. 1, 167.

Hosie, K. F. (1962) Thermal-dilution technics. Circulation Res. 10, 491.

Kety, S. S. (1960) Peripheral blood flow measurement-blood tissue exchange methods. In: Methods in Medical Research, Vol. 8, pp. 230-235. Ed. H. D. Bruner. Year Book Publishers, Chicago.

Korner, P. I. (1965) The effect of section of the carotid sinus and aortic nerves on the cardiac output of the rabbit. F. Physiol., Lond. 180, 266.

MaCmillan, E. W. (1954) Observations on the isolated vaso-epididymal loop and on the effects of experimental subcapital epididymal obstructions. Proc. Soc. Study Fert. 6, 57.

Martan, J. \& Risley, P. L. (1963) Holocrine secretory cells of the rat epididymis. Anat. Rec. 146, 173.

Mason, K. E. \& Shaver, S. L. (1952) Some functions of the caput epididymis. Ann. N.Y. Acad. Sci. $55,585$.

Neutze, J. M., Wyler, F. \& Rudolph, A. M. (1968) Use of radioactive microspheres to assess distribution of cardiac output in rabbits. Am. 7. Physiol. 215, 486.

Nicander, L. (1957) Studies on the regional histology and cytochemistry of the ductus epididymis in rabbits. Acta morph. neerl.-scand. 1, 99.

NIGANDER, L. (1965) An electron microscopical study of absorbing cells in the posterior caput epididymis of rabbits. Z. Zellforsch. mikrosk. Anat. 66, 829.

Orgebin-Crist, M. C. (1968) Maturation of spermatozoa in the rabbit epididymis: delayed fertilization in does inseminated with epididymal spermatozoa. F. Reprod. Fert. 16, 29.

Orgebin-Crist, M. C. (1969) Studies of the function of the epididymis. Biol. Reprod. Suppl. 1, 155.

Reid, B. L. (1958) Some cytological features of epididymal cells in the rat. Q. $\mathcal{F l}$ microsc. Sci. 99, 295.

ReId, B. L. \& Cleland, K. W. (1957) The structure and function of the epididymis. I. The histology of the rat epididymis. Aust. F. Zool. 5, 223.

Sapirstein, L. A. (1956) Fractionation of the cardiac output of rats with isotopic potassium. Circulation Res. 4, 689.

SAPIRstein, L. A. (1958) Regional blood flow by fractional distribution of indicators. Am. F. Physiol. 193,161 .

SApirstein, L. A. (1962) Measurement of the cephalic and cerebral blood flow fractions of the cardiac output in man. F. clin. Invest. 41, 1429.

SAPIRStein, L. A. (1967) The indicator fractionation technique for the study of regional blood flow. Gastroenterology, 52, 365.

Scott, T. A., Wales, R. G., Wallace, J. G. \& White, I. G. (1963) Composition of ram epididymal and testicular fluid and the biosynthesis of glycerylphosphorylcholine by the rabbit epididymis. 7. Reprod. Fert. 6, 49.

Setcheld, B. P. (1970) Testicular blood supply, lymphatic drainage, and secretion of fuid. In: The Testis, vol. I, pp. 101-239. Eds. A. D. Johnson, W. R. Gomes and N. L. VanDemark. Academic Press, New York.

Setchell, B. P., Wartes, G. M. H. \& Till, A. R. (1964) Variations in flow of blood within the epididymis and testis of the sheep and rat. Nature, Lond. 203, 317.

Shaver, S. L. (1954) The role of stereocilia in removing India ink particles from the lumen of the rat epididymis. Anat. Rec. 119, 177.

Smith, H. G. \& Waites, G. M. H. (1969) Blood flow in the brain and reproductive organs of the conscious rabbit before and during ovulation. Aust. F. exp. Biol. med. Sci. 47 (6), 25. 
Thorburn, G. D., Kopald, H. H., Herd, J. A., Hollenberg, M., O’Morchoe, G. G. G. \& Barger, A. C. (1963) Intrarenal distribution of nutrient blood flow determined with Krypton ${ }^{85}$ in the unanaesthetised dog. Circulation Res. 13, 290.

Toothill, M. C. \& Young, W. C. (1931) The time consumed by spermatozoa in passing through the ductus epididymis of the guinea pig as determined by means of India ink injections. Anat. Rec. $50,95$.

Tuck, R. R., Setchell, B. P., Wartes, G. M. H. \& Young, J. A. (1970) The composition of fluid collected by micropuncture and catheterization from the seminiferous tubules and rete testis of rats. Pflügers Arch. ges. Physiol. 318, 225.

van Wagenen, G. (1924) Degeneration of the germinal epithelium in the testis of the rat as a result of efferent duct ligation. Anat. Rec. 27, 189.

van WAGENEN, G. (1925) Changes in the testis of the rat following ligation of the ductuli efferentia. Anat. Rec. 29, 339.

Voglmayr, J. K., Waites, G. M. H. \& Setchell, B. P. (1966) Studies on spermatozoa and fluid collected directly from the testis of the conscious ram. Nature, Lond. 210, 861.

Wattes, G. M. H. \& SETchels, B. P. (1966) Changes in blood flow and vascular permeability of the testis, epididymis and accessory reproductive organs of the rat after the administration of cadmium chloride. F. Endocr. 34, 329.

Young, W. C. (1931) A study of the function of the epididymis. III. Functional changes undergone by spermatozoa during their passage through the epididymis and vas deferens in the guinea pig. F. $\exp$. Biol. 8, 151. 